\title{
Trauma and Sacrifice in Divided Communities: The Sacralisation of the Victims of Terrorism in Spain
}

\author{
Eliana Alemán ${ }^{1, *(D)}$ and José M. Pérez-Agote ${ }^{2, *}$ \\ 1 Departament of Sociology and Social Work, Universidad Pública de Navarra, \\ 31006 Pamplona, Navarra, Spain \\ 2 I-Communitas, Institute for Advanced Social Research, Universidad Pública de Navarra, \\ 31006 Pamplona, Navarra, Spain \\ * Correspondence: eliana.aleman@unavarra.es (E.A.); jose.perez.agote@unavarra.es (J.M.P.-A.)
}

Citation: Alemán, Eliana, and José M. Pérez-Agote. 2021. Trauma and Sacrifice in Divided Communities: The Sacralisation of the Victims of Terrorism in Spain. Religions 12: 104. https://doi.org/10.3390/rel12020104

Academic Editors: Javier Gil-Gimeno, Josetxo Beriain and Celso Sánchez

Received: 15 January 2021

Accepted: 30 January 2021

Published: 4 February 2021

Publisher's Note: MDPI stays neutral with regard to jurisdictional claims in published maps and institutional affiliations.

Copyright: (c) 2021 by the authors. Licensee MDPI, Basel, Switzerland. This article is an open access article distributed under the terms and conditions of the Creative Commons Attribution (CC BY) license (https:/ / creativecommons.org/licenses/by/ $4.0 /)$.

\begin{abstract}
This work aims to show that the sacrificial status of the victims of acts of terrorism, such as the 2004 Madrid train bombings ("11-M") and ETA (Basque Homeland and Liberty) attacks in Spain, is determined by how it is interpreted by the communities affected and the manner in which it is ritually elaborated a posteriori by society and institutionalised by the state. We also explore the way in which the sacralisation of the victim is used in socially and politically divided societies to establish the limits of the pure and the impure in defining the "Us", which is a subject of dispute. To demonstrate this, we first describe two traumatic events of particular social and political significance (the case of Miguel Ángel Blanco and the 2004 Madrid train bombings). Secondly, we analyse different manifestations of the institutional discourse regarding victims in Spain, examining their representation in legislation, in public demonstrations by associations of victims of terrorism and in commemorative "performances" staged in Spain. We conclude that in societies such as Spain's, where there exists a polarisation of the definition of the "Us", the success of cultural and institutional performances oriented towards reparation of the terrorist trauma is precarious. Consequently, the validity of the post-sacrificial narrative centring on the sacred value of human life is ephemeral and thus fails to displace sacrificial narratives in which particularist definitions of the sacred Us predominate.
\end{abstract}

Keywords: sacrifice; cultural trauma; victims of terrorism; ritual; performance

\section{Introduction: Sacrifice, Terrorism and Ritual}

In this article, we seek to show that the sacrificial status of the victims of acts of terrorism such as the 2004 Madrid train bombings (referred to in Spanish and hereinafter as 11-M) and ETA (Basque Homeland and Liberty) attacks in Spain does not occur in a closed form but is subject to different interpretations by those affected by the attacks. We argue that the sacrificial sacralisation of the victims is, in reality, ritually elaborated a posteriori by society and institutionalised by the state. We also explore the way in which the sacralisation of the victim is used in socially and politically divided societies to establish the limits of the pure and the impure in the dispute regarding the definition of the "Us".

To demonstrate this thesis, we hermeneutically address the relationship between sacrifice and terrorism, highlighting the process whereby social representations of the victims are elaborated. In doing so, we shall make reference to two types of empirical reality drawn from Spanish society. On the one hand, we describe two traumatic events of particular social and political significance (the case of Miguel Ángel Blanco and 11-M), which are the subject of collective processes of a cultural nature. On the other hand, we analyse different manifestations of the institutional discourse on victims in Spain, examining their representation in legislation, in public demonstrations by associations of victims of terrorism and in commemorative "performances" staged in Spain. 
Ever since Hubert and Mauss published their seminal study in 1899, sacrifice has come to be seen as a ritual act in which the participants take on a sacred nature, in such a way that the sacrificial offering passes from the commonplace to the religious. This is a central element of the religious experience and is characteristic of Neolithic agricultural cultures and societies. Although it entails a complex procedure that can take multiple forms and be used for the most diverse purposes, it invariably establishes "a means of communication between the sacred and the profane worlds through the mediation of a victim, that is, of a thing that in the course of the ceremony is destroyed" (Hubert and Mauss 1899, p. 76). Thus, the total or partial destruction of the offering, albeit only in vegetable form, is an essential feature of the sacrifice.

However, in order for the victim to pass from the common to the religious domain, it must be consecrated by means of a series of ritual operations that purify it, so that it will act as an intermediary between the sacrifier ${ }^{1}$ - the individual or collective subject to whom the benefits of sacrifice accrue - and the divinity to whom the sacrifice is generally made. The success of the sacrificial ritual, argue Hubert and Mauss (1899), depends on each of the steps assigned to the participating elements-sacrifier, sacrificer, instruments, victim and divinity-performing their role in perfect continuity, without interruption and in the prescribed order. Otherwise, the powerful and destructive forces involved would turn against both the sacrifier and the sacrificer.

Evidently, the sacrificial narrative that Hubert and Mauss describe cannot be precisely mapped to the present day. Social and civilisational changes have transformed the role of ritual in general and sacrifice in particular. The sacrificial logic they describe, centring as it does on the immolation of the victim, would later be rejected by Christianity. On the grounds that "it is criminal to kill the victim because he is a sacred being", Christianity counters with a post-sacrificial narrative centring on "the anti-sacrificial sacralisation of the human individual", from whose secularised re-interpretation we get the human rights legislation of modern societies, as described by Durkheim (1973) and Joas (2019), Beriáin (2017, pp. 658-59). At the same time, despite broad consensus throughout the twentieth century on Hubert and Mauss's work, a number of alternative explanations have been postulated, such as Girard's influential hypothesis of substitution. Girard extends the anti-sacrificial narrative to Neolithic societies, arguing that "There is no question of 'expiation.' Rather, society is seeking to deflect upon a relatively indifferent victim, a 'sacrificeable' victim, the violence that would otherwise be vented on its own members" (Girard 2005, p. 8).

In determining the role of sacrifice in modern societies, we need to consider two important issues. Firstly, in such societies, the ritual form loses its capacity to perform its social function effectively and is thus replaced by a cultural performance. According to Jeffrey Alexander, in less differentiated and complex societies, the participation of community members in the ritual regenerates social cohesion. However, in more complex and differentiated contemporary modern societies, the ritual is not capable of maintaining the fusion in itself; social performance is the type of experience that can re-fuse the social elements that have lost their cohesion (Alexander 2006, 2017). This, however, does not mean that the narrative of the sacrificial ritual vanishes when the practice of cultural performance is extended. On the one hand, this is no more than a quasi-ritual practice; and on the other, contemporary social agents keep alive the narrative of the sacred significance of the ritual in many of their social practices. In the political domain, moreover, social performance requires the establishment of binary differences between a pure sacred and civic "Us", and its opposite, a contaminated, profane and anticivic "Them", as well as the emergence of heroic figures capable of making audiences feel the authenticity of these binary differences until re-fusion is attained. Achieving that impression of authenticity is a requisite for convincing the audience.

1 TRANSLATOR'S NOTE: I have used the term "sacrifier", coined by the English translator of Hubert and Mauss's original work, as a translation for sacrificante in Spanish (sacrifiant in the original French), for which there is no exact English equivalent. 
Secondly, modern societies have introduced new variants of the sacred, which coexist and compete with former representations of the divinity. Thus, at different moments in time, realities such as the nation, the proletariat, the individual and democracy have all been sacralised. Elsewhere in this collection, Josetxo Beriáin makes reference to this aspect when he describes the clash that occurs in these societies between the sacrificial and the antisacrificial narrative (Beriáin 2021). From a post-Durkheimian perspective, this is endorsed by Bernhard Giesen when he links the collective identity to "the sacred", denoted by extraordinary moments or experiences that escape ordinary classification because of their exceptional capacity for transcendence. "The sacred stands for the collective identity of a social community" when the way in which the self-referential narrative of the collective self interprets its collective identity does not square with the real and visible representations of this collective self (Giesen 2006, p. 329). Ritual and performance communicate the sacred world of the collective identity with the profane world of their real and visible representations, thus constructing that "elementary communitas that transcends social cleavages and unites the body social" (Giesen 2006, p. 342). ${ }^{2}$

In order to understand how society and the state sacralise the victims of terrorism, we need to consider the role of all the elements taking part from the perspective of ritual, paying particular attention to the victim and to the way in which the sacred-on whose behalf this offering is made-is defined. In today's societies, dynamically diverse definitions of the sacred exist alongside one another, and their hierarchical status varies depending on the intensity and authenticity of the ritual performances in which they are activated, and the relationships binding the communities to which both victim and sacrificer belong.

The Girardian hypothesis of the scapegoat is often used to define the victim. From our perspective, however, it is of only limited use, since when it appears, it does so in a non-sacrificial form, accompanying a socially more relevant interpretation, as Hénaff notes, arguing that not all victims are sacrificial ${ }^{3}$. Therefore, adds Hénaff, we must not confuse sacrifice with victimisation. ${ }^{4}$ Although Christ was indeed a scapegoat, his crucifixion, presented by Girard as the sacrifice of an innocent victim drawing visibility for the first time to the arbitrariness and injustice of sacrifice (Beriáin 2017, p. 657), was in fact no more than the execution of an agitator at the hands of the political power, argues Hénaff. And he concludes: "The sacrifice of Christ only occurred in a posteriori readings in evangelical preaching" (Hénaff 2002, p. 425).

Here, we need to be specific on the notion of terrorism and its ritual dimension. Beyond the very generic mention of terrorism as political violence exercised in the name of a social or political cause, not only have experts in this phenomenon been incapable of reaching any consensus whatsoever as to its definition; the divergence has only widened in the last forty years (Schmid 2011; Zulaika and Douglass 1990, 1996, 2008). While recognising the difficulty of establishing a stable concept as a starting point, for practical purposes, this work accepts the distinction between "old" and "new" terrorism. ${ }^{5}$ This does not, however, signify that we necessarily validate all the features commonly attributed to each type. We need only clarify that by "old terrorism", we mean the kind practised during the second half of the twentieth century, and by "new terrorism", we refer to the sort that emerged from the mid-1990s (with the attacks on the World Trade Center in New York in 1993 and

2 Communitas: a concept coined by Turner to designate a unique form of solidarity that occurs in the liminal phase of a transitional ritual between two positions of status. The liminal moment dissolves the normative constraints and levels status distinctions among ritual participants; it fosters the creation of the communitas, in which ritual participants are brought closer to the primordial and existential, distancing them from their cognitive ties to the structured, normative social order and fusing them in a simple community of equals (Alexander 2017, pp. 53-54; Turner 1969).

3 Nonetheless, in the idea of violence as an inherent attribute of sacrifice-implicit in the scapegoat-Giesen sees a resource for awarding the supreme authenticity required for success of the ritual (Giesen 2006, p. 337).

4 "Sacrifice is an act that presupposes an addresser and an addressee. It is, above all an irreversible offering to an invisible beneficiary whose response must be obtained, hence the immolation. As in ceremonial gift-giving, something of one's own must be offered-hence the choice of a domestic animal. The fact that the immolated victim is called a victim does not mean that every victim is a sacrificed being. Lynchings, executions, or massacres are not sacrifices but victimization procedures" (Hénaff 2002, pp. 424-25).

5 See Blanco and Cohen (2016) about the distinction between "old" and "new" terrorism. 
on the Tokyo subway in 1995), which took on a whole new dimension following the attacks of 11 September 2001. The forms that fall under the category of "old terrorism" act in the name of different causes, including religion, class and ethnic or national community. Of all of these, ethno-terrorism is especially significant (Zulaika and Douglass 1996). In contrast, the category of new terrorism is largely monopolised by Islamic fundamentalism.

Insofar as terrorism is an extremely polyhedral phenomenon, it cannot be reduced to a single, univocal pattern of action. Nonetheless, it contains a markedly ritualistic dimension within which one can identify participants and rites of passage and exit that frame the attack as a hierophanic element in which the sacred is manifested (Eliade 1985). In our case, the sacred coincides with the collective identity, in the form of the nation (for ETA) and the ummah or community of believers (for Al-Qaeda). The attack is the symbolic event that breaks the banal continuity of social order and their everyday secular lives (Giesen 2006, p. 327). It is "a ritual action that introduces a discontinuity into the ordinary course of events" (Zulaika 1991, p. 221). The fact that the victim is selected at random guarantees his or her innocence, giving the event an inexplicable character for its audience; unable to find a causal rationality for the victim's immolation, the audience feels more vulnerable to terror (Zulaika 1991; Zulaika and Douglass 1996). For ETA's defenders, its "members are priestly figures charged with the sacred function of defending the homeland; for its detractors, in contrast, they are the compendium of the most irrational danger and most abhorrent bestiality" (Zulaika 1991, p. 224).

The fact that the diverse manifestations of terrorism have a ritual character does not mean per se that the terrorist act or attack constitutes a sacrificial ritual. For this to be the case, the immolated victim must represent the sacrifier, be it an individual or a community. The sacralisation of the sacrificial victim must symbolise an exchange in which something of value -the victim - taken from the secular domain is consecrated, enabling a communion between the sacrifier and the sacred, whose favour (i.e., the fusion between the sacrifier and the sacred divinity) it is hoped to receive in return. Hence the difficulty of establishing a correspondence between terrorism and sacrifice, a problem that not all approaches to this phenomenon have been able to resolve. ${ }^{6}$

Nevertheless, the sacrificial sacrality of the victim of a terrorist attack may be subject to different interpretations. When the prevailing feature in the community from which the victim is taken is any particularist variant of a sacred "Us" - such as the nation-the immolation is not sacrificial, since it is not an offering by the community to which he or she belongs. However, the need to repair the cultural trauma caused makes it necessary to sacrificially sacralise the victim, in such a way that this community can maintain a quasi-sacrificial narrative and transmute itself a posteriori into the sacrifier community, or to appeal to the post-sacrificial narrative by making the sacralisation of the universalised human individual prevail over any other form of particular sacralisation. For the terrorist sacrificer, on the other hand, the immolation of the victim is only sacrificial in two cases. The first is when the sacrificer himself faces the risk of losing life or liberty or when he self-immolates, finding death. In this case, he is sacralised by his own community, but the target victim of his attack is not. The second case is when the victim is assigned the role of the scapegoat of the sacrifier community. In all other cases (the majority), it is seen simply as a necessary process of victimisation to achieve a specific goal.

\section{Traumatic Events in a Divided Society}

We cannot understand the reaction of Spanish society to terrorist attacks without considering the social and political polarisation forged by an original cultural trauma ${ }^{7}$ that has not found civil reparation and which has fed and been fed by the superimposition of

6 See, for example, the interpretation of the Real IRA attacks in Omagh (Ireland) and of ETA's killing of a bus driver in Itziar (Basque Country) in Dingley and Kirk-Smith (2002).

7 "Cultural trauma occurs when members of a collectivity feel they have been subjected to a horrendous event that leaves indelible marks upon their group consciousness, marking their memories forever and changing their future identity in fundamental and irrevocable ways" (Alexander 2004). 
different forms of violence exercised against different types of victim. ${ }^{8}$ The transition to democracy after the period of Civil War and subsequent dictatorship of the victor, General Franco, did not result in a reparation for the victims from the losing side, nor for their families, who are still battling to have their remains-which were dumped in mass gravesrecovered and identified..$^{9}$ Indeed, during the transition period, a hegemonic memory was imposed on the Civil War, whereby all Spaniards were equally to blame for what happened, denying the traumatic nature of its origins (Izquierdo 2017). Nor have the victims of the repression meted out under the dictatorship as yet received any reparation.

\subsection{The Kidnapping and Murder of Miguel Ángel Blanco by ETA}

ETA (Basque Homeland and Liberty) was set up in 1959 as an armed national liberation movement (Pérez-Agote 1984). ${ }^{10} \mathrm{It}$ aspired to the regeneration of Basque nationalism under the Franco dictatorship and rejected the appeal to race and religion traditionally defended by the Basque Nationalist Party (PNV). Amongst its creeds, it included socialism and a defence of the working class (Gurruchaga 1988; Zulaika 1991). ETA carried out its first assassination in 1968. By July 1997, it had killed 776 victims (De la Calle and Ignacio 2004). During the closing years of the Franco dictatorship, its actions were viewed with sympathy by opponents of the regime throughout Spain. This was especially true of its assassination of Admiral Carrero Blanco, Franco's prime minister and most likely successor, in 1973.

ETA emerged as a utopian and transgressive force in opposition to the violence of the state, notes Tejerina (2015). For many years, it primarily targeted members of the security forces, thus garnering strong support from radical nationalist sectors in the Basque Country, well into the period of the democratic transition (1975-1982). At the same time, however, it entirely lost any backing it had had elsewhere in Spain, and with the conclusion of the transition, its support among Basque nationalist circles also began to wane. ${ }^{11}$ The goal of its strategy, according to De la Calle and Ignacio (2004), was to force the state to accept its demands and to control the population; it tried to reinforce this control by spearheading mobilisation for all kinds of social causes (Tejerina 2015). In short, a division was already becoming apparent in Basque society between those who supported ETA violence, those who rejected it and those who remained ambivalent, who embodied certain contradictions between rational and sentimental assessments (Pérez-Agote 1984).

In 1995, ETA began a new strategy, called the "socialisation of suffering", whereby it widened its repertoire of potential victims to extend the fear to society as a whole. This ended up catalysing mobilisation against the group (Gorospe 2018). Until 1997, the growing social opposition, in which pacifist movements and victims' associations (the first was created in 1981) played an important role (Mateo Santamaría 2018), had only a limited impact. However, everything changed that summer, when ETA lost its social legitimacy, thus beginning the road to the cessation of its armed activities (2011) and its ultimate dissolution (2018), leaving a final toll of 853 deaths.

On Thursday 10 July 1997, ETA announced that it had kidnapped Miguel Ángel Blanco, a councillor for the People's Party (Partido Popular) in Ermua, a small town in the Basque province of Biscay. ETA handed the government—and the People's Party-an ultimatum, giving it $48 \mathrm{~h}$ to bring the 600 ETA prisoners dispersed in prisons throughout Spain back to the Basque Country. ${ }^{12}$ The action came in direct response to an operation ten days before by the security forces, in which they had successfully freed prison officer

8 On trauma in culturally divided communities, see Tognato (2013).

9 Although there is no consensus on the number of victims of the Civil War, recent research estimates that counting the combatants, those killed in the reprisal attack, executions and the victims of Franco's repression after the war, the death toll comes to around 600,000 (e.g., Preston 2012).

10 See De Pablo (2018) for the controversy on the date of ETA's foundation.

11 Support from radical nationalists in the Basque Country was strengthened by the dirty war waged against ETA by sectors of the security forces remaining from the dictatorship (González 2012; Woodworth 2001).

12 This measure, which is still in place, was intended by the state to hinder ETA's control over its prisoners. 
José Antonio Ortega Lara, who had been held hostage by the group for over a year. ${ }^{13}$ ETA acted out a ritual performance whose script envisaged two possible outcomes to the drama: either the victim would be executed or (an unlikely option) the prisoners would be relocated. Either would convincingly demonstrate to the audience, Spanish society, ETA's capacity to bend the state to its will. In effect, the government did not give in to the blackmail and when the deadline ran out, Miguel Ángel Blanco was found with his hands bound and two shots to the head. He died several hours later in hospital.

What the script that ETA had drawn up did not envisage was that from the very moment in which its communiqué was made public, it would trigger an overwhelming counter-performance driven by the uninterrupted coverage of the events in the media, which fed and was fed by an unprecedented social response. The media reported live on the progress of the search, declarations by a great range of public figures (including King Juan Carlos and the Pope) and citizen acts of protest. To facilitate the search, authorisation was also given to publish personal and family pictures and information on the councillor, leading to a complete identification by the audience with the victim. In short, the media provided the script of a counter-performance which served to sustain a climate of maximum intensity (catexis) over a two-day period and which also raised hopes that the victim might be saved.

Within this counter-performative framework, two sets of highly dramatic mobilisations were staged, constituting what Beriáin calls an expiatory rite of national mourning "that turned the secular death of an innocent into a grand sacred symbol" (Beriáin 2016, p. 109). The vigil of lit candles, played out on the night before the assassination in the square in front of the town hall in Ermua, reached a performative climax among all those protagonised by local people from the town, regardless of their political persuasions. In a study based on interviews with members of Elkarri and Gesto por la Paz, Funes tells how the vigil revived memories of the night before the last executions of the Franco era in 1975, and how the identification of ETA with Franco, for its intolerance and authoritarianism, "allowed the emotion of those hours to be augmented by emotions from the past" (Funes 1998, p. 102). It was, she adds, a catharsis that condensed in that event a process of change that was already underway and which entailed a broad social consensus with regard to the delegitimisation of violence for political ends (Sabucedo et al. 2000). The "spirit of Ermua" was born, a representation of the indignant and unanimous rejection of ETA violence by Spanish society and, in Basque society, the breaking of a spiral of silence. Throughout the rest of the country, mobilisations were held in practically every city and town. Participants in the protests held on the morning of the 12th-the largest since the years of the transition — exhibited the blue ribbon and whitewashed hands that had been used to symbolise opposition to ETA since the kidnapping of Julio Iglesias Zamora in 1993 and the murder of Federico Tomás y Valiente in 1996, respectively. Although the largest demonstrations were in Madrid and Barcelona, the most significant and emotional was the one held in Bilbao, the provincial capital of Biscay, which was headed by the prime minister, José María Aznar, and many of his ministers.

The ritual phase of this counter-performance stretched from the publication of ETA's communiqué on the afternoon of the 10th (ritual entry) until Blanco's funeral on Monday the 14th (ritual exit). Structurally, it centred around two liminal moments, the kidnapping and the murder, against which the collective mobilised, attaining a state of collective effervescence or communitas. The result of this communitas was that, in that moment, communities that had been divided over conflicting definitions of the national sacred fused, extolling the sacredness of the individual over any such divisions. This mutation of the hierarchical order of the sacred, in which priority is given to the sacredness of human life, restores the sacrificial nature of the victim, whose sacralisation forms the threshold for initiating a process of civil reparation of the cultural trauma experienced by the collective.

13 Some time later, the press reported that, before ETA issued its communiqué, the Minister of the Interior's secretary received a threatening call, saying: "You bastards, you're going to pay for what happened with Ortega Lara. Long live the Free Basque Country!". 
Of course, this communitas fades in time and the pre-existing order to which the divided communities pay allegiance is re-established. Nonetheless, as Turner has noted, once the ritual performance is over, reality has been transformed. Ultimately, this marked the beginning of the end for ETA. ${ }^{14}$

\subsection{The 11-M Jihadist Attacks in Madrid}

Islamic terrorism, says Alexander, is a post-political phenomenon representing the end of political possibilities, including both the most immediate possibilities, such as creating successful Arab states in the Middle East, and the more utopian possibilities, such as turning the ummah into a single great Moslem state. To this end, it seeks to create political and social instability by assassinating key leaders, sowing fear and obliging the authorities to adopt repressive measures that delegitimise its institutional network (Alexander 2017, pp. 200-1). Although Spain has suffered its consequences since the mid-1980s, until the beginning of the twenty-first century, the intelligence services did not believe it had the means to mount a terrorist attack on Spanish soil. Spain had become a jihadist target because of its participation in the Iraq War (Comisión de Investigación Sobre el 11 de Marzo de 2004 2005).

On 11 March 2004, Al-Qaeda carried out a series of bombings in which 192 people lost their lives and over 1800 were injured (Comisión de Investigación Sobre el 11 de Marzo de 2004 2005). ${ }^{15}$ Ten bombs exploded during the morning rush hour on four trains heading towards Atocha station in Madrid, creating a scene of carnage, with hundreds of dismembered bodies strewn amongst the debris. Certain parallels can be traced between the collective reactions to the 9/11 attacks in the US and the 11-M bombings in Madrid. As in the case of 9/11 (Alexander 2017), the terrorist performance was initially received in triumph by the audience at which it was aimed. A report in The New Yorker related the satisfaction with which Al-Qaeda and its followers received news of the attacks:

"An Al Qaeda statement posted on the Internet after the March 11th bombings declared, 'Being targeted by an enemy is what will wake us from our slumber'". (Wright 2004)

A post on Facebook went further:

On March 12th, the day after the train bombings, a message titled "The Goals of Al Qaeda in Attacking Madrid" had been posted by a writer calling himself Gallant Warrior. Echoing a theme that is frequently repeated on these sites, the writer noted that by carrying out its threat to Spain, Al Qaeda proved that its words were matched by actions: "Al Qaeda has sent a message to the crusading people: do not think that death and fear are only for the weak Muslims. ... Aznar, the American tail, has lost. And great fear has spread among the people of the countries in alliance with America. They will all be vanquished. Thank God for letting us live this long to see the jihad battalions in Europe. If anyone had predicted this three years ago, one would have said he was dreaming". (Wright 2004)

And on ikhwan.net:

A writer named Murad chastised those who condemned the Madrid bombings. "You pity the deaths of those non-Muslims so quickly! If Muslims had died in their lands in the manner the writer discusses, would he have cried for them?" A woman named Bint al-Dawa responded, "Brother Murad, Islam does not allow the killing of innocent people." A man who called himself "Salahuddeen2" entered the discussion: "We have said that we are against the killing of civilians anywhere, but the enemies of God kill Muslim civilians every day and do not feel shame. They should drink from the same bitter cup". (Wright 2004)

14 Even the media changed the way in which they reported their attacks (Caminos et al. 2013).

15 It is the second bloodiest attack in Europe after Pan Am flight 103, brought down over Lockerbie in 1988 (Pérez-Ventura 2014). 
However, as in New York, the general public quickly mobilised. Thousands of Madrileños turned out to offer assistance to the victims at the scene of the attack, donating blood and giving whatever support they could. Anonymous heroes appeared, alongside the police, firefighters, health workers and psychologists, giving help to the victims. From that same day, ordinary citizens began a sort of pilgrimage to the site of the bombings, leaving all kinds of offerings to commemorate the victims. Altars were set up throughout the city, in the victims' workplaces, at iconic monuments and in businesses and shops. The citizenry took over the public space to sacralise it and commemorate the dead, but also to demand information and accountability (Ortiz García 2008).

A performance was being staged that rejected fear and which, in those initial moments, managed to fuse its audience, the entire country, in a community that unwaveringly espoused the sacred value of human life, intuiting a script that centred on a post-sacrificial narrative. However, unlike the aftermath of the 9/11 attacks, politicians and media commentators failed to provide a single interpretation of the facts that might create the script extolling the collective self-resisting adversity in the name of sacrosanct human life. This would have been an essential element for turning the performance that was already underway into a successful counter-performance in opposition to the performance of terror.

With general elections due to be held just three days after the attacks, the government, motivated by partisan interests, launched a campaign of disinformation, pointing the finger at ETA as the perpetrators of the crime, despite prima facie evidence to suggest that it had been committed by Islamic terrorists (Comisión de Investigación Sobre el 11 de Marzo de 2004 2005). ${ }^{16}$ ETA's denials of involvement were scorned, as was a video issued on behalf of Al-Qaeda, claiming responsibility (Catalán 2005). Many Spanish media fell in line with the government position (Sampedro Blanco 2009). In the face of growing doubts among the public, the government resorted to tactics of intimidation, denouncing those who questioned their version as "contemptible". On 12 March, the government unilaterally called a demonstration against terrorism. The march in Madrid was fronted by a banner replicating one of the slogans used in the pre-electoral campaign, "Con las víctimas, con la Constitución y por la derrota del terrorismo" ("With the victims, with the constitution and for the defeat of terrorism"). The demonstrators, however, chanted back, “¿Quién ha sido?" ("Who was it?").

In short, the public were asked to choose between believing the government or believing ETA. Despite media efforts, the pre-existing climate of opinion did not favour the government's campaign. ${ }^{17}$ As a result, the audience which in the initial performance had fused around the sacralisation of human life, split into two groups, those who accepted the sacrificial narrative of the government and those who rejected it, maintaining the post-sacrificial narrative. The media and politicians appealed to them, deploying the collective representations of the "Us" that divide Spanish society around its original trauma ${ }^{18}$, unleashing a political struggle in which each side tried to present itself as a pure and sacred "Us" in contrast to the "Other", associated with the impure and contaminated. ${ }^{19}$ Unlike the cases of the 9/11 attacks and that of Miguel Ángel Blanco, it did not manage to manufacture a successful counter-performance that could clearly prevail over the terrorist performance. And this partly achieved the goal of destabilising Spanish society, socially,

16 After the Madrid attacks, one of Prime Minister Aznar's advisers apparently said to him: "If it was ETA, we'll win by a landslide, but if it was the jihadists, the PSOE will win" (Ortega Dolz 2019).

17 The mass protests held the previous year against Spain's participation in the Iraq War, a decision taken unilaterally by Prime Minister Aznar, were still very present. Ninety-one percent of Spaniards were opposed to the war and $80 \%$ considered that it harmed the country (Centro de Investigaciones Sociológicas CIS 2003). In February 2003, this rejection had led over three million people to turn out in Madrid and Barcelona under the slogan “№ a la guerra!" ("No War!”), the largest protests since the murder of Miguel Ángel Blanco (Martínez-Fornes 2003).

18 Divins (2016) also sees a relationship between the political conflict aroused by the interpretation of the attack and the Civil War, over whose memory a pact of silence had been imposed by the Transition.

19 One example was the accusations levelled against the Socialist Party by the People's Party for organising 20,000 people to protest in front of the PP's offices on the 13th, despite the fact that the event was a "flash" protest, spread by text message (Sampedro Blanco 2009). 
politically and morally, intensifying the conflict on the definition of the sacred "Us" and the role played in it by the sacrificial sacralisation of the victims of terrorism.

\section{Institutionalisation of the Sacrificial Sacralisation of the Victims}

\subsection{From Invisibility to Protagonism of the Sacrificed Victim}

The institutionalisation of the sacrificial sacralisation of the victims that came with the 1999 Solidarity with the Victims of Terrorism Act (SVTA) ${ }^{20}$ constitutes part of a process of civil reparation of the cultural trauma that had begun with the communitas that emerged following the kidnap and murder of Miguel Ángel Blanco. Before that date, there had been performances of solidarity with the victims, such as the mass turn-out for the funeral of the President of the Provincial Government of Gipuzkoa, Juan María Araluce, in 1976 and protests at the murder of the engineer José María Ryan in 1981. However, under the Franco dictatorship, anti-terrorist legislation included no provision favouring the victims (Serranò 2018), and during the transition, they received only very limited attention from the authorities. ${ }^{21}$ The $9 / 11$ attacks in the US and the 11-M attacks in Madrid drove changes to the legislation on victims, particularly the 2011 Recognition and Comprehensive Protection of Victims of Terrorism Act (RCPVTA). ${ }^{22}$

There was a shift from a period of invisibility to one in which the victims became the protagonists, whose suffering came to be considered as being a priority and a unifying force (Boutellier 2000). This epochal phenomenon also occurred in Spain (Mateo Santamaría 2018). The change was to affect social representations centring on the victims and the role played by their associations. In Spain, although the initial drive for recognition of the victims came from these organisations, growing support from the institutions meant that between 1988 and 2018, their numbers swelled from eight to thirty-eight, of which three were devoted to the victims of the 11-M attacks (Mateo Santamaría 2018). This reflects the diversity of outlooks with regard to the role of the victims and views on anti-terrorist policy.

The SVTA was presented as a way of honouring and recognising the sacrifice of the victims of terrorism. The law defined the victims as those people who, in sacrificing their life or their freedom, exhibited and defended the values of society. Given that, at the time it was passed into law, the category of "victim" was colonised by the victims of ETA, they were positioned in the sacred ambit by the representations which the state began to institutionalise through laws and performances. At the same time, in the debate on the RCPVTA, some parties on the left suggested that the victims' sacrifice for the benefit of society should be considered as involuntary (Amendment \# 52). However, this amendment was not passed.

According to the RCPVTA, the victim is a symbol; it states that by attacking the victim, the aim is to attack the values of society and the rule of law, and thus confers a political significance on the victim. The victim emerges as a sacrificial offering by means of which it is hoped to achieve the emotional adhesion of the community to the institutions, reinforcing their link with the nation-state. In the absence of heroes or martyrs who had selfimmolated in the name of the nation, their place is taken by the victims of terrorism. ${ }^{23}$ Thus, the institutional narrative makes an effort to present them as sacrificially sacralised victims.

This representation, elaborated a posteriori, should be successful, if we bear in mind that in secularised societies with a fragmented morality, the victim becomes a moral refer-

Ley 32/1999 de Solidaridad con las Víctimas del Terrorismo.

Royal Decree Law 3/1979 on protection of the public security in which the state assumed responsibility for issuing compensation to the victims.

2 Ley 29/2011 de Reconocimiento y Protección Integral a las Víctimas del Terrorismo.

23 As stated above, according to Hénaff, victims of terrorist attacks are not always sacrificial. Furthermore, strictly speaking, a distinction must be made between martyr, national hero and suicide bomber, as they represent different historical manifestations of the post-sacrificial narrative. As Beriáin (2007) indicates, the martyrs embody the post-sacrifice narrative introduced by Christianity; they are victims who know that they are going to die and who choose to do so by endowing their death with a solidarity meaning with a discriminated group. In the process of modern secularization, the national hero takes the martyr's place, so the duty of dying for the country provides meaning to his potential death. The suicide bomber rises in late or global modernity as a reinvention of the historical archetype of the martyr, signifying both the duty to die for the ummah and the rejection of Western modernity. 
ence such that "Durkheim's organic solidarity has dissolved into a victimalised solidarity" (Boutellier 2000). When there is a consensus as to what the victim represents, the social legitimacy that the victim enjoys extends to the institutions that defend him or her, and each mutually feed of one another. However, in Spain, this aspect proved problematic, because the institutional narrative on the victims of terrorism clashed with the sacrificial narratives that established the hierarchical orders of the national sacred in conflict.

\subsection{The Delimitation of the Pure and the Impure}

The new context of international terrorism that emerged following the $9 / 11$ attacks in the US facilitated the adoption of certain political measures in Spain, which could be defended as being part of the cause of the victims of terrorism. Prime Minister Aznar seized the opportunity to declare that "all terrorisms" were alike, equating ETA with Bin Laden. He tried to force through the illegalisation of Batasuna, the radical left-wing Basque nationalist party, which the government considered to act as a support for ETA (Anasagasti 2007). He managed to establish new legal and symbolic limits with regard to the pure and the impure that took concrete form in the 2002 Political Parties Act ${ }^{24}$, which drew a distinction between those organisations that acted with respect for democracy and those that based their political action on collusion with terror, violence and the violation of human rights. The enactment of the law led to the banning of Batasuna, judicial persecution of its milieu and the stigmatisation of anyone who opposed the concept of democracy extolled in the Act. From that moment on, there was an intensification in the tabooisation of the terrorist, which was considered to contaminate anyone coming into contact with it (Zulaika and Douglass 1996)..$^{25}$

An order was imposed, along the lines established by Douglas (1991), which redefined "the Us" by tracing the outlines of all that was clearly out of place and threatened that just order, representing the danger, the dirty and the contaminating. An attempt was made to unite the community in protecting itself from a common threat, under pain of contamination and moral opprobrium. "The Us" was thus redefined with the victims of terrorism of ETA at its core. Violating the taboo not only meant being excluded but also calling into question the sacrifice of the victims, something which could not be tolerated in a sacrificial narrative built on the logic of confrontation.

The 11-M attacks extended the map of terrorist victims and perpetrators. However, the government tried to impose the representation of the pure and the impure that it had constructed in reference to ETA terrorism. Identifying ETA as the perpetrator of the 11-M attacks was presented as a moral conviction. Aznar could have drawn a likeness between the two terrorisms, as he had before, but the events demonstrated a difference in nuances between "old" and "new" terrorism. These nuances introduced ambivalence, ambiguity and indecisiveness into a representation based until then on a clear dichotomy. The government even went so far as to suggest that the attacks had been organised jointly by ETA and Al-Qaeda (Catalán 2005). Another sacred element had to be invoked to reestablish the binary logic. Despite the fact that national reconciliation is enshrined in the Spanish constitution, a distinction was drawn between "constitutionalists and nonconstitutionalists", the latter being relegated to the realm of the impure.

The imposition of this rigid binary logic hindered any consensus as to those whom the RCPVTA should recognise as victims; victims of state abuse, victims of the Franco dictatorship and victims of other terrorist organisations with political objectives were all excluded, despite opposition from nationalist and left-wing parties. For this reason, no mention is made of any specific group of victims. Moreover, the law considered democratic participation to be incompatible with organisations that represent or justify terrorism. In short, any flexibilisation in the limits set out (such as the inclusion of other victims) was

24 Ley Orgánica 6/2002 de Partidos Políticos.

25 This taboo remains operative to this day. In 2018, for example, Alfonso Sánchez, President of the Association of Victims of Terrorism (AVT), was removed from his post for holding institutional encounters with leader of the Basque nationalist left (Ballesteros 2018). 
interpreted as a betrayal of "the" victims of terrorism that would signify whitewashing the perpetrator or imposing a "falsified" memory.

\subsection{Decorations as Functional Substitutes for Purification Rituals}

Decorations are a response to victims' need for a civil recognition or reparation, associated with remembrance and commemoration. In their process of resilience, the victims must be able to see that it is they and not the terrorists who are at the heart of society's attention (Ivankovic et al. 2017). The SVTA created the Royal Order of Civil Acknowledgement of Victims of Terrorism ${ }^{26}$ as a recognition of their sacrifice. The order's Grand Cross (Gran Cruz) was awarded posthumously to those killed in terrorist attacks and a Commendation (Encomienda) to those who had been injured or kidnapped. With the amendment to this law in 2003, a further step was taken towards a legislative delimitation of the pure and the impure as applied in Spain. Victims were required to have an untainted personal background to be eligible for decoration. The values set out in the Constitution, human rights and laws on victims of terrorism were added to the realm of the pure. This criterion was maintained in the RCPVTA, which moreover added that the victims' social recognition derived from their political significance and it was held up as a tool for the ethical, social and political delegitimisation of terrorism.

The inclusion of new requirements for receiving decorations is probably related to an institutional concern that some victim of a terrorist act might not "really" represent the social values generically attributed to him/her. The public and individualised recognition of victims who do not represent those values would constitute a transgression of the established limits, hence the need to guarantee their purity. The decorations become functional substitutes for purification rituals, necessary in order to declare the victim's innocence, which is no longer presumed solely by virtue of the unjust violence suffered. In the ceremonies at which the decorations are awarded, there is a ritual remembering and the sacrificial sacralisation involves a process whereby the institutional structure guarantees that the victim effectively embodies values that it wishes to prevail and considers to be sacred.

Thus, the public conferrals of the medals become performances in which, at the same time as the victim is exalted, the values of the regime are reinforced. The occasion is commonly used to delegitimise-with the collusion of the self-styled constitutionalist parties - those who reject the victors-and-vanquished logic and call for recognition of all victims. In this context, the distinction between victims who deserve decoration and those who do not is enshrined in a dynamic of confrontation: only the victim who can function as a scapegoat, freeing the group from all blame, is worthy of civil recognition. Paradoxically, the distinction between victims prevents the entire community from coming together and fusing around the sacrificially sacralised victim; indeed, it actually foments division. Even victims of the 11-M attacks who have received institutional recognition feel excluded by this logic. One such individual, Antonio Miguel Utrera (Fundación Víctimas del Terrorismo 2020), called on the authorities in the following terms: "I ask you to accompany and defend us from those who brandish the flag of hatred and attack us. However, I ask you not to accompany or support us if our claims are marked by the hatred or sense of victimisation that leads to revenge".

\subsection{Tributes to the Victims in Divided Communities}

In Spain, tributes to victims of terrorism have not always fomented unity. Different performances of solidarity with victims have also served communities with different identitary references to reaffirm their concept of the "Us". One example of this dynamic can be seen in the acts scheduled in parallel in two Basque locations in June 1995. One section of Basque society went to the "concert for peace" to demand that ETA release the engineer José María Aldaya, kidnapped some months after the killing of councillor

26 Real Orden de Reconocimiento Civil a las Víctimas del Terrorismo. 
Gregorio Ordoñez (Barbería 1995) Another sector, sympathetic to Batasuna, expressed its indignation at the way in which the bodies of ETA militants, Lasa and Zabala, murdered in 1983 by GAL, had been interred (Guenaga 1995). Some of the speakers at the concert called for an end to violence in the Basque Country and argued that certain judicial and police actions repel the general public. In the tribute to Lasa and Zabala, there were chants against those who wore blue ribbons and a banner with the face of the two young men, stating "you cannot kill the soul of a people", in an effort to identify their victims with those of all of Basque society.

This division began to be weakened following the communitas that arose out of the kidnapping and killing of Miguel Ángel Blanco. In order to maintain the spirit of communion, the Aznar government sought to institutionalise it through performances, such as the concert held in Madrid in September 1997 to pay homage to Blanco, which was broadcast on state television. Under the slogan "United for Peace", artists representing different identities and political persuasions took part in the act. One of the acts was Valencian singer-songwriter Raimon, who was introduced as a Catalan who deserved thanks for inspiring people to learn other languages and to know, respect and love a nation's signs of identity. Raimon presented his performance as a contribution to the "fight against death", choosing the song "País Vasc" (Basque Country), which he had written during the years of the dictatorship. The song, a tribute to the suffering of the Basque people, was sung in the Valencian language, and the singer-songwriter took the opportunity to remind his audience that the language had been banned several times during the Franco dictatorship. ${ }^{27}$ This earned him booing from a section of the crowd, which attempted to disrupt the performance. ${ }^{28}$ The incident appeared to show that the fusion experienced as a communitas had been short-lived and that it would not be simple to overcome the history of divisions in which a given interpretation of the "unity" of Spain has been sacralised above other pluralist forms of viewing coexistence.

It is clear to see the binary logic that has been extended to other social representations that end up relating the domains of the pure and the impure with other-also sacralisednotions. The different nationalisms that coexist within Spain (Spanish, Basque, Catalan and Galician) and the identitary issues linked to them are juxtaposed, when they are not combined, with aspects of a different nature, such as those related to solidarity, empathy and identification with the suffering of the victims of terrorism.

For their part, the institutions continued to step up performances of recognition of the victims in a continuous attempt to appeal to that unity surrounding them. The RCPVTA meant greater institutionalisation of those acts, providing support for victims to participate in all institutional acts that affected them. It also declared 27 June as a day of remembrance and homage to the victims and 11 March as the commemoration of the European Day of Victims of Terrorism. Other forms of recognition and remembrance of the victims included acts, symbols, monuments and similar elements.

These recognitions were linked to the effective reparation and the core ideas of the new legislation were defined as being "remembrance, truth, justice and dignity". However, these ideas were also framed in the discourse of victor/vanquished, in which full reparation to the victim involves a firm anti-terrorist policy that brooks no form of complicity. Despite the apparent clarity of this approach, it is nonetheless problematic when, for example, the different victims' associations (or the victims considered individually) struggle to discover "the truth" or interpret the overcoming of their trauma in different ways.

The separate tributes of different victims' associations and political parties fed the division, transmitting that split to society as a whole. This division increases the risk that the cause of the victims may be politicised by a political party or by associations of victims

27 The recognition of Spain's linguistic plurality is the subject of political dispute. A structured review of linguistic repression can be found in Torrealdai (1998).

28 El dia que Raimon va ser xiulat per cantar en valencià (https:/ / www.youtube.com/watch? v=NBAF-dihiko\&feature=youtu.be) (accessed on 20 November 2020). 
that want to impose their own anti-terrorist policy. This weakens the cause of the victims, since doing justice through reparation for the personal and social damage caused requires both social recognition of the victims and a healing of the social fracture caused by the crime (Mate 2008).

The commemoration of the 11 March attacks is an example of the existing social and political division. Year after year, two of the leading victims' associations, Asociación 11M Víctimas and the AVT (Association of Victims of Terrorism), stage separate performances in Madrid, which are attended by different political representatives. Both organisations continue to demand that the full truth be made known, but in opposing senses. While the former recalls the untruths of Aznar, the second insinuates the existence of hidden police reports that would provide a different version of the events (Clemente 2017).

The political parties also foster the division. This can be seen in the Day of Remembrance in the Basque Country for recognition of the victims: "Since the day was first commemorated in 2010, it has been marked by divisions as to the significance of the date and the category of victims" (Lecumberri 2018). ${ }^{29}$ So, for example, there have been years in which left-wing Basque nationalist parties did not attend because the tribute did not include the victims of all forms of violence. However, when the victims of politically motivated violence and police abuse were included, the People's Party did not attend.

The institutional recognition of the victims of terrorism contrasts with the public welcoming ceremonies for ETA members released from prison, appearing to play out a competition for the performative recognition of sacrificed heroes. The AVT has denounced the fact that this type of "tribute" offends and humiliates them and have even taken the matter to the courts (Gorospe 2019). Arnaldo Otegi, leader of the Basque nationalist left, answers that "they do not do it humiliate anyone but to welcome a person who is returning to his town" (Izarra 2019) and that the problem lies in the interpretation given by others to such receptions. Insofar as the receptions for ETA members revive the trauma experienced by their victims, they reinforce the binaries that categorise ETA in the realm of the impure; it also reinforces the very survival of that binary logic that is opposed to the emergence of a more integrating collective memory.

In short, the sacrificial sacralisation of the victim also extends to the sacralisation of his or her memory, whose purity is jealously guarded so that the sacralised and heroic victim is not sullied. The victims were the object of victimisation, but all the institutional narrative a posteriori, accompanied by certain performative acts, portrays them as heroic victims. This sacrificial commemoration is reminiscent of a state in war which requires an identifiable enemy, but which today not only faces less distinct threats (such as jihadist terrorism) but increasingly sees itself impelled to incorporate a post-sacrificial logic in which the sacrality of the person is imposed over any other hierarchical order of the sacred.

\section{Conclusions}

The killing of Miguel Ángel Blanco and the 11-M attacks questioned society by transforming the way in which it addressed terrorism. Insofar as the suffering of the victims became a collective suffering, a society that was divided over the memory of the original trauma and the trauma of terrorism achieved moments of fusion. Here, one can see the role of the performance in the process of the victims' sacralisation and also the prevalence of a post-sacrificial narrative in the communitas that had arisen in the moment of social effervescence. However, neither the crime against Blanco, nor 11-M, nor even the dissolution of ETA have, for the time being, managed to make that fusion permanent. Despite the transformation that has occurred, when the communitas is dissolved and there is a return to the institutionalised structure, the sacrificial logic re-emerges. The sacrificial and post-sacrificial narratives coexist, conditioned by the fact that Spain is a divided society, sustained on binary and exclusive representations. This is projected in the social represen-

29 The date of the celebration has great significance: "The 10 November, the only day in the calendar on which there have been no victims of terrorist acts" (Lecumberri 2018). 
tations of an ideal order in which the victim of terrorism, subjected to functional substitutes of purification established by the institutions, becomes the focal point in the delimitation of the pure and the impure. These narratives become caught up in the dispute over the definition of the "Us". And as long as this does not find a channel through which it can be resolved, it will indeed be difficult to reach a consensus that can overcome the ambivalence with regard to the two narratives, in such a way that the anti-sacrificial logic prevails.

Finally, this type of analysis - the narratives on the victims - could also be applied to other contexts. For instance, exploring and establishing connections with the process of victims' identity recovery and construction in dictatorships and violent conflicts like the ones in Latin America or in post-Fascist Italy.

Author Contributions: Conceptualisation, E.A. and J.M.P.-A.; methodology, E.A. and J.M.P.-A.; formal analysis, E.A. and J.M.P.-A.; investigation, E.A. and J.M.P.-A.; resources, E.A. and J.M.P.A.; writing-original draft preparation, E.A. and J.M.P.-A.; writing—review and editing, E.A. and J.M.P.-A. All authors have read and agreed to the published version of the manuscript.

Funding: This research received no external funding.

Acknowledgments: To the I-Communitas Institute of the Public University of Navarra for funding of translation.

Conflicts of Interest: The authors declare no conflict of interest.

\section{References}

Alexander, Jeffrey C. 2004. Toward a Theory of Cultural Trauma. In Cultural Trauma and Collective Identity. Edited by Jeffrey C. Alexander, Ron Eyerman, Bernard Giesen, Neil J. Smelser and Piotr Sztompka. Berkeley: University of California Press, pp. 1-30.

Alexander, Jeffrey. 2006. Social performance between ritual and strategy. In Social Performance.Symbolic Action and Cultural Pragmatics. Edited by Jeffrey C. Alexander, Bernhard Giesen and Jason L. Mast. Cambridge: Cambridge University Press, pp. 29-90.

Alexander, Jeffrey. 2017. Poder y Performance. Madrid: CIS.

Anasagasti, Iñaki. 2007. De cómo nos Opusimos a la Ley de Partidos y Cómo nos Quedamos Más Solos Que la Una. EAJ-PNV. Available online: https:/ / www.eaj-pnv.eus/es/documentos/6336/de-como-nos-opusimos-a-la-ley-de-partidos-y-como-n (accessed on 9 October 2020).

Ballesteros, Roberto. 2018. Terremoto en la AVT: Las Víctimas 'Echan' al Presidente por Reunirse con 'Abertzales'. El Confidencial. Available online: https://www.elconfidencial.com/espana/2018-04-05/avt-victimas-terrorismo-alfonso-sanchez_1544670/ (accessed on 9 October 2020).

Barbería, José L. 1995. 18.000 Personas Reclaman en el Concierto por la Paz el fin de la Violencia en Euskadi. El País. Available online: https:/ / elpais.com/diario/1995/06/25/espana/804031210_850215.html (accessed on 9 October 2020).

Beriáin, Josetxo. 2007. Chivo expiatorio-mártir, héroe nacional y suicida-bomba: Las metamorfosis sin fin de la violencia colectiva. Papers 84: 99-128. [CrossRef]

Beriáin, Josetxo. 2016. Formas modernas de resacralización en disputa. La nación y la persona. Revista Internacional de Sociología 74: 1-13.

Beriáin, Josetxo. 2017. Las metamorfosis del don: Ofrenda, sacrificio, gracia, substituto técnico de Dios y vida regalada. Politica y Sociedad 54: 641-63.

Beriáin, Josetxo. 2021. The Endless Metamorphoses of Sacrifice and its clashing narratives. Religions 11: 684. [CrossRef]

Blanco, José M., and Jéssica Cohen. 2016. Viejo y Nuevo Terrorismo. Enfoque 2. Centro de Análisis y Prospectiva. Gabinete Técnico de la Guardia Civil. Available online: https://intranet.bibliotecasgc.bage.es/intranettmpl/prog/local_repository/documents/1787 3.pdf (accessed on 15 April 2020).

Boutellier, Hans. 2000. Crime and Morality: The Significance of Criminal Justice in Post-Modern. Dordrecht: Kluwer Academic Publisher.

Caminos, José M., José Ignacio Armentia Vizuete, and Flora Marín Murillo. 2013. El asesinato de Miguel Ángel Blanco como ejemplo de key event en el tratamiento mediático de los atentados mortales de ETA. adComunica. Revista de Estrategias, Tendencias e Innovación en Comunicación 6: 139-60. Available online: http:/ / repositori.uji.es/xmlui/bitstream/handle/10234/78366/130-332-1-PB.pdf? sequence $=1 \&$ isAllowed $=y$ (accessed on 15 April 2020).

Catalán, Miguel. 2005. Prensa, Verdad y Terrorismo: La Lección Política del 14-M». El Argonauta Español 2. Available online: http:/ /journals.openedition.org/argonauta/1191 (accessed on 4 November 2020). [CrossRef]

Centro de Investigaciones Sociológicas CIS. 2003. Barómetro de Febrero 2003. Estudio n ${ }^{\mathrm{o}} 2.481$. Available online: http:/ / www.cis.es / cis/export/sites/default/-Archivos/Marginales/2480_2499/2481/Es2481.pdf (accessed on 20 October 2020).

Clemente, Enrique. 2017. Las Víctimas del 11M Exigen Trece Años Después Que se Sepa Toda la Verdad. La Voz de Galicia. Available online: https: / www.lavozdegalicia.es/noticia/espana/2017/03/12/victimas-11m-exigen-trece-anos-despues-sepa-verdad/ 0003_201703G12P18991.htm (accessed on 20 October 2020). 
Comisión de Investigación Sobre el 11 de Marzo de 2004. 2005. Texto Aprobado por el Pleno del Congreso de los Diputados, en su Sesión del Día 30 de Junio de 2005, Resultante del Dictamen de la Comisión de Investigación Sobre el 11 de Marzo de 2004 y de los Votos Particulares Incorporados al Mismo. Boletín Oficial de las Cortes Generales, VIII Legislatura, $\mathrm{n}^{\circ}$ 424. Available online: http:/ / www.congreso.es/public_oficiales/L8/CONG/BOCG/D/D_242.PDF (accessed on 6 September 2020).

De la Calle, Luis, and Sánchez-Cuenca Ignacio. 2004. La selección de víctimas en ETA. Revista Española de Ciencia Política 10: 53-79.

De Pablo, Santiago. 2018. Julio de 1959: El nacimiento de ETA. Historia Actual Online 48: 45-59. Available online: https://historiaactual.org/Publicaciones/index.php/hao/article/view/1689 (accessed on 15 November 2020).

Dingley, James, and Michael Kirk-Smith. 2002. Symbolism and Sacrifice in Terrorism. Small Wars \& Insurgencies 13: 102-28.

Divins, Thomas J. 2016. Four Days that Transformed Spain 11-M Impact on Memory Recovery Examined through the Lens of Duality. Master's thesis, West Virginia University, Morgantown, VA, USA. Available online: https:/ / researchrepository.wvu.edu/etd/5501 (accessed on 30 November 2020). [CrossRef]

Douglas, Mary. 1991. Pureza y Peligro: Un Análisis de los Conceptos de Contaminación y Tabú. Madrid: Siglo XXI.

Durkheim, Émile. 1973. Individualism and the Intellectuals. In Emile Durkheim on Morality and Society. Edited by Robert Bellah. Chicago: University of Chicago Press, pp. 43-57.

Eliade, Mircea. 1985. Lo sagrado y lo Profano. Barcelona: Editorial Labor.

Fundación Víctimas del Terrorismo. 2020. Homenaje del Ministerio del Interior a las Víctimas del Terrorismo. Revista de la Fundación Víctimas del Terrorismo 70: 23. Available online: http:/ / fundacionvt.org/wp-content/uploads/2020/05/fvt70.pdf (accessed on 9 October 2020).

Funes, María J. 1998. La Salida del Silencio. Movilizaciones por la paz en Euskadi 1986-1998. Madrid: Akal.

Giesen, Bernhard. 2006. Performing the sacred: A Durkheimian perspective on the performative turn in the social sciences. In Social Performance, Symbolic Action and Cultural Pragmatics. Edited by Jeffrey C. Alexander, Bernhard Giesen and Jason L. Mast. Cambridge: Cambridge University Press, pp. 325-67.

Girard, René. 2005. La Violencia y lo Sagrado. Barcelona: Anagrama.

González, Juan Manuel González. 2012. La violencia política de la extrema derecha durante la Transición española (1975-1982). Coetánea. In Actas del III Congreso Internacional de Historia de Nuestro Tiempo. Edited by Carlos Navajas Zubeldia and Diego Iturriaga Barco. Logroño: Universidad de La Rioja, pp. 365-76.

Gorospe, Pedro. 2018. Teoría y Práctica de la Socialización del Sufrimiento. El País. Available online: https://elpais.com/politica/2018 /04/28/actualidad/1524913595_360804.html (accessed on 20 October 2020).

Gorospe, Pedro. 2019. El Parlamento Vasco Rechaza los Recibimientos a Presos de ETA que Apoya la Izquierda 'Abertzale'. El País. Available online: https:/ / elpais.com/politica/2019/10/03/actualidad/1570092352_863926.html (accessed on 20 October 2020).

Guenaga, Aitor. 1995. Homenaje a Lasa y Zabala en Tolosa Tras una Jornada de Lucha con 10 Detenidos. El País. Available online: https:/ / elpais.com/diario/1995/06/25/espana/804031211_850215.html (accessed on 20 October 2020).

Gurruchaga, Ander. 1988. El código Nacionalista vasco Durante el Franquismo. Barcelona: Anthropos.

Hénaff, Marcel. 2002. The Price of Truth. Gift, Money and Philosophy. Stanford: Stanford University Press.

Hubert, Henri, and Marcel Mauss. 1899. Essai sur la Nature et la Fonction du Sacrifice. Année sociologique tome II: 29-138. Available online: http:/ / classiques.uqac.ca/classiques/mauss_marcel/melanges_hist_religions/t2_sacrifice/Melanges_2_sacrifice.pdf (accessed on 15 April 2020). [CrossRef]

Ivankovic, Aleksandra, Levent Altan, and An Verelst. 2017. How Can the EU and the Member States Better Help Victim of Terrorism? Brussels: Policy Department for Citizens' Rights and Constitutional Affairs.

Izarra, Josean. 2019. Arnaldo Otegi Anuncia Que "Habrá 250 Recibimientos Más a Presos". El Mundo. Available online: https: / / www.elmundo.es/pais-vasco/2019/08/02/5d4406e0fc6c83ec168b464f.html (accessed on 20 October 2020).

Izquierdo, Jesús. 2017. Memoria normalizada: 1936 en la España de la impunidad. Rey Desnudo Año VI 11: 119-34.

Joas, Hans. 2019. La sacralidad de la Persona. Una Nueva Genealogía de los Derechos Humanos. Buenos Aires: UNSAM EDITA.

Lecumberri, Jokin. 2018. La Unanimidad Imposible del Día de la Memoria en Euskadi. La Vanguardia. Available online: https: / / www.lavanguardia.com/local/paisvasco/20181110/452801301467/dia-de-la-memoria-pais-vasco-unanimidadterrorismo-eta-violencia-victimas.html (accessed on 20 October 2020).

Martínez-Fornes, Almudena. 2003. El «No a la Guerra» Reúne la Mayor Protesta Desde el Asesinato de Miguel Ángel Blanco. $A B C$. Available online: https://www.abc.es/internacional/abci-no-guerra-reuneynbsp-mayor-protesta-desde-asesinato-miguelangel-blanco-200302160300-162383_noticia.html (accessed on 20 October 2020).

Mate, Reyes. 2008. Justicia de las Víctimas. Terrorismo, Memoria y Reconciliación. España: Anthropos.

Mateo Santamaría, Eduardo. 2018. La contribución del movimiento asociativo y fundacional a la visibilidad de las víctimas del terrorismo en España. Revista de Victimología 7: 9-46. [CrossRef]

Ortega Dolz, Patricia. 2019. El Gobierno de Aznar me Pidió que Asumiera su Mentira Sobre el 11-M. El País. Available online: https:/ / elpais.com/politica/2019/03/10/actualidad/1552221291_945279.html (accessed on 20 October 2020).

Ortiz García, Carmen. 2008. Memoriales del atentado del 11 de marzo en Madrid. Cadernos de Estudos Africanos 15: 47-61. [CrossRef]

Pérez-Agote, Alfonso. 1984. La Reproducción del Nacionalismo: El Caso Vasco. Madrid: Siglo XXI.

Pérez-Ventura, Óscar. 2014. La amenaza de Al-Qaeda en España diez años después del 11-m. Revista Aequitas 4: $389-409$.

Preston, Paul. 2012. The Spanish Holocaust: Inquisition and Extermination in Twentieth-Century Spain. London: HarperPress. 
Sabucedo, José Manuel, Mauro Rodríguez, and W. López López. 2000. Movilización social contra la violencia política: Sus determinantes. Revista Latinoamericana de Psicología 32: 345-59.

Sampedro Blanco, Víctor. 2009. Conspiración y pseudocracia. O la esfera pública a cinco años del colapso del 11-M. Viento Sur 103: 60-68. Available online: https://cdn.vientosur.info/VScompletos/Sampedro.pdf (accessed on 20 October 2020).

Schmid, Alex P. 2011. The Routledge Handbook of Terrorism Research. New York: Routledge Handbooks, Taylor and Francis.

Serranò, Agata. 2018. Las víctimas del Terrorismo: De la Invisibilidad a los Derechos. Madrid: Thomson Reuters Aranzadi.

Tejerina, Benjamín. 2015. Nacionalismo, violencia y movilización social en el País Vasco. Factores y mecanismos del auge y declive de ETA. Papeles del CEIC 3: 136. [CrossRef]

Tognato, Carlo. 2013. Extending Trauma Across Cultural Divide: On Kidnapping and Solidarity in Colombia. In Narrating Trauma: On the Impact of Colective Suffering. Edited by Ron Eyerman, Jeffrey C. Alexander and Elizabeth Butler Breese. Boulder and London: Paradigm Publishers.

Torrealdai, Joan Mari. 1998. El Libro negro del euskera. Donostia: Ttarttalo.

Turner, Victor M. 1969. The Ritual Process: Structure and Anti-Structure. Chicago: Aldine Publishing Company.

Woodworth, Paddy. 2001. Dirty War, Clean Hands: ETA, the GAL and Spanish Democracy. Cork: Cork University Press.

Wright, Lawrence. 2004. The Terror Web. Were the Madrid bombings part of a new, far-reaching jihad being plotted on the Internet? The New Yorker. April 2. Available online: https:/ / www.newyorker.com/magazine/2004/08/02/the-terror-web (accessed on 15 November 2020).

Zulaika, Joseba. 1991. Reyes, políticos, terroristas: La función ritual de ETA en relación al nacionalismo vasco. Revista de Antropología Social 0: 217-30.

Zulaika, Joseba, and William A. Douglass. 1990. On the Interpretation of Terrorist Violence: ETA and the Basque Political Process. Comparative Studies in Society and History 32: 238-57.

Zulaika, Joseba, and William A. Douglass. 1996. Terror and Taboo. The Folies, Fables and Faces of Terrorism. New York and London: Routledge.

Zulaika, Joseba, and William A. Douglass. 2008. The terrorist subject: Terrorism studies and the absent subjectivity. Critical Studies on Terrorism 1: 27-36. [CrossRef] 